\title{
An Approach to Building Learning Objects
}

\section{Peter Thaysen}

Ressource and Project Center, SmartLearning, Copenhagen, Denmark.

\begin{abstract}
Designing for online education can be a complex endeavor and the way to approach this must be carefully considered. This article examines the case of Danish educational institution SmartLearning to map out and analyze the approach to online courses. The study find that SmartLearning approaches the online courses by setting up guidelines for educators on how to build learning objects. The approach is to use three different elements, one focused on the content and learning goals for a course, one focused on the layout of the leaning management system, and one focusing on which didactic principles to apply. These three elements must work together in the learning object in order to assure learning and motivation of learners. The study also find some structure regarding this process and based on the analysis it is recommended to bind the development of learning objects and courses together through instructional design tools. This will aid the further development of combining the three elements into quality learning objects.
\end{abstract}

Keywords: Learning Objects; E-learning; Continued education; Online course design. 


\section{Introduction}

The background for this paper is the interest in mapping out how modern educational institutions can create online courses with consideration to both user friendliness, quality of education and easy to use development tools for educators in the continuous designing of online courses. Focus will partly be a new didactic guideline in SmartLearning, and partly the basic rules for designing learning objects to be easy to access.

\section{Case description and methodology}

SmartLearning is the case study used in this paper, an institution owed by eight Danish business academies and charged with the responsibility to handle all fully online courses in the area of continued education (further adult education) on behalf of the academies. SmartLearning offers thirteen different educations and a series of smaller micro learning courses. The educational levels are academy profession programs and diploma graduate programs, which were attended by 3.187 learners in 2019. SmartLearning is located in Copenhagen, Denmark, but since all teaching takes place on SmartLearning's Moodle platform, placement really does not mean much to the operations. Because of this SmartLearning can work with educators all over Denmark and therefore employ many parttime employees. Because of these virtual aspects of the operation challenges lies in the organization of the educators and courses, which becomes crucial to success (Danmarks Evalueringsinstitut, 2019). Strong processes and clear roles are necessary to develop and maintain this type of organizational structure (Larsen et al., 2016). Because of this, the organization decided to develop common processes and define new roles for learners. This to ensure the quality of the courses offered by SmartLearning. The methodology is observations, educational materials and feedback from learners and educators from both courses and training seminars for educators. I have analyzed the structure and design of 26 courses containing 364 learning objects. Further 2-3 learner evaluation surveys per course and for about 15 sets of course evaluation data extracted from analytical tools in Moodle. This was carried out as qualitative analysis, working with educators and digital learning consultants on structure and design of learning objects and creating general guidelines for this work. I have participated in three two-day workshops and three one day workshops with the educators on topics of developing online courses, designing learnings objects, using evaluations, using analytical tools in Moodle and applying didactic principles.

\section{Approaching learning object design}

At SmartLearning, the design of learning objects has several elements to it, and I have decided to divide these elements into different approaches to designing learning objects. The approaches are sliced content in an appropriate amount, the layout of the Moodle platform, 
and the didactics to be used in order to secure learning and student participation. Learnings objects in this case is referred to as a lesson. I comprises both instructions, teaching materials, exercises and evaluation. A typical course consists of 14 such themed objects and a general section functioning as a frame for the entire course.

\subsection{The components of an online learning object}

First, there must be sliced pieces of content. Slicing the content of the course creates small chunks of learning with appropriate learning targets. Slicing is beneficial to learning, because typically, the brain is not able to handle more than 3-4 new concepts at a time, as there is limited rage in the short-term memory (Boser, 2017, p. 41). At the same time, the chunks must not be too small at to become trivial or neglectable.

Then there need to be a structure. It must be easy for a student to move from one learning object to another. It should not be a challenge for the learners to orientate themselves in a new learning object, so they should be predictable in their structure. This is achieved on the level of the organization by creating a baseline for the structure of learning objects (SmartLearning, 2019I). This baseline is built on some general design principles, in SmartLearning the principles are: fast, functional, familiar. Fast in regards to how easy, it is to navigate the learning objects, and learning platform as a whole. There should not be many layers and it must be easy to jump between objects and parts of objects. Each course is then a series of linked learning objects and what we could call a general object containing the overall course information. Functional refers to that each specific element in the learning object must be easy to use and have a singular purpose. Because of this, interdependence between parts it not used a lot, but there can be a forced succession in some tasks. Familiar refers to the learning objects are based on the same baseline for design. These three design principles ensures that further development of learning objects does stay within a common framework and adhere to common quality standards. Part of the baseline also outline what data points there should be available in the design and which dashboard element should be available to learners and educators respectively.

The third element is the didactic principles, which I will examine in the next section.

\subsection{The didactic principles at SmartLearning}

A learning object need to contain a number of activities, either reading text, writing text, problem solving, quizzing, the possibility to engage in peer to peer activities, watching video, making video, co-creation with fellow learners and so forth. All this need to be tied together in a way, which ensures the highest learning outcome and the highest level of participation on the part of the learners. Because of this, an adequate toolbox of didactic principles must be available to all the educators at SmartLearning. This is especially important since most teachers are working part-time at SmartLearning (and usually full time in another 
organization), and are working from all over the country. These virtual aspects of the organization, where most learners only meet once or twice a year, makes the sharing of knowledge less than seamless. This calls for a higher degree of facilitations on behalf of the organization, especially in terms of the development and use of online learning objects, since this is not normally a focus point in the other (usually educational) organization where the educators are employed full time.

There are many learning principles that can be employed when designing learning objects, but the principles primarily used at SmartLearning will together address a wide variety of approaches to learning so that the educators can choose from different approaches, but approaches that still support each other. The principles are: Spaced Practice \& Retrieval, Cognitive overload, Variation, Personalized learning, Online socialization, Transfer and Metacognition (SmartLearning, 2019II). By utilizing these principles in the design of online learning objects and whole courses, improvements in both retention and motivation can is monitored and measured. It is important that the course designers have a clear idea about which principles to use before beginning to design the learning object.

Measurement for retention of knowledge is handled with quizzes, surveys and polls along reports and other written exercises. Quizzes, surveys and poll are easily applied in an online environment, and yield quantitative data of successes and failures, and weather learners can recall knowledge from the course. Measurement for motivation can take the form of registering participation in discussion forums, peer-to-peer exercises, but also in general course statistics such as frequency of login, time spend in the learning environment and by using weekly surveys of learner satisfaction with the course.

\subsection{Organizational setup}

All responsibilities of SmartLearning's educational activities lies within what is called the 'column of education'. As mentioned, most educators are part-time at SmartLearning, but a small handful of full time educators are employed and function as coordinators. These coordinators assist the educators in updating the courses in relation to curriculum design and combining the individual courses that makes up full formal educations. There are also specific course designers employed called Digital Learning Consultants, who do not teach, but work only on assisting educators in using the guidelines and the Moodle platform in general alongside guiding educators in using the didactic principles online. This means that three functions exists in the column of education: teaching, structuring courses in Moodle (baseline) and didactic support. It is important that these three functions work closely together. Most importantly, this is aiming at ensuring that the educators can focus on their teaching and teaching methods. Put in another way, the educators can focus on ensuring the learning output and motivation of the learners. This is quite a significant change form earlier, when educators were expected to develop and design everything independently, but now 
designer and educator is not necessary the same person, so a specialization is taking place within this setup at the organization.

\subsection{Future developments}

The development in SmartLearning towards a structured approach to ensuring quality and innovation in education has gained traction over some years now, but initiatives are not necessary seen within a cohesive framework. More in depth analysis is needed for this. However, based on this study an overarching framework can be outlined which can be used to structure the principles and guidelines mentioned in this paper. In building learning objects (and combining these into full courses), I find there must be three elements working in accord and these are content, baseline and didactic principles as shown in figure 1.

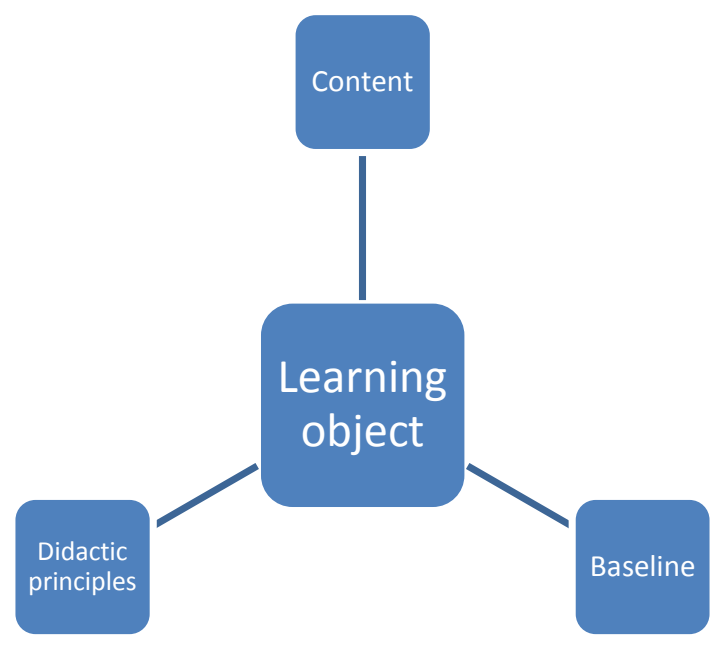

Figure 1. The three elements of building learnings objects.

These three element interacts as a process of mutual adjustment. Development of content and implementing baseline are the two processes that have progressed the furthest. Developing and securing the quality of the content is handled by the coordinators and educators together, and the baseline have been updated a couple of times since the first version. Educators and the digital learning consultants in collaboration have handled subsequent programs of implementation. The processes that led to the development of the role of the coordinator and the development of the baseline began in 2015. The process towards the guidelines for the didactic principles began in 2019 by introducing them to the educators and encouraging educators to implement and experimenting. This process is set to be formalized in the spring of 2020 with the digital learning consultants assisting the educators in the process of setting 
up targets, implementing and executing the didactic principles in learning objects (SmartLearning, 2020). Evaluation processes will follow this.

The approach to creating learning objects at SmartLearning is a process in rapid development. From an organizational perspective there has to be careful planning and plan for execution with everyone in the organization knowing their role to ensure all the different components interact properly. Continued study of, reflections on, and development of these processed could yield further improvement in performance at SmartLearning.

\section{Recommendations}

Based on this study I find the three elements described could use a more formalized method in practice. From the information, I have collected it is my estimate, that the focus should be on measurable outcomes amongst learners, using predictable learning outcomes as target points. Based on this the design of courses and course elements can take the form of instructional design. Instructional design is useful for designing learning objects (Patel et al., 2018) and with the SAM model (Successive Approximation Model) the designer can benefit from a more dynamic approach to instructional design in online education (Jung, 2019). Because of the nature of online learning objects, and the idea of developing fundamental principles for learning throughout the organization, I can see a particular benefit to operate within the SAM framework. This because it allows the developers to design and test in sprints and therefore can change direction fast if needed, and at the same time allows for maintenance and continuous improvement of courses from semester to semester. This flexibility is important because if SmartLearning is to capitalize fully on their ability to respond fast to feedback from learners and analytics data, both during and after courses are run. Development of the learning objects can then be organized in a development cycle consisting of three steps: analyze, design, development. For the reason that cycles can be applied both during and after courses are run, online learning objects should always be considered works in process. As new data accumulates with each course run, and new developments in didactics provides new tools for learners, the learning objects can be continuous improved in regards to both content, baseline layout and didactic principles.

\section{References}

Boser, U. (2017): Learn Better. New York, NY: Rodale.

Danmarks Evalueringsinstitut (2019): Erfaringer med digitalisering af VEU. Retrieved October 10, 2019, from https://www.uvm.dk/aktuelt/nyheder/uvm/2019/maj/190503-nyrapport-afdaekker-erfaringer-med-digitaliseringen-af-veu 
Jung, H., Kim, Y., Lee, H. \& Shin, Y. (2019): Advanced instructional design for successive e-learning: Based on the Successive Approximation Model (SAM). International Jl. on E-learning (2019) 18(2), 191-204. Retrieved January 12, 2020, from https://www.researchgate.net/publication/331829482_Advanced_Instructional_Design for_Successive E-Learning_Based on the Successive_Approximation_Model_SAM

Larsen, H. H., Hjalager, A-M., Kjær, S., \& Jørgensen, T. M. (2016): Virtuel ledelse \& arbejdsmiljø - i praksis. Bind 2. Rapport fra forskningsprojekt støttet af Arbejdsmiljøforskningsfonden. Copenhagen Business School, Syddansk Universitet, COWI A/S.

Patel, S. R., Margolies, P. J., Covell, N. H., Lipscomb, C. \& Dixon, L. B. (2018): Using instructional design, analyze, design, development, implement and evaluate, to develop e-learning modules to disseminate supported employment for community behavioral health treatment programs in New York State. Frontiers in public health, 2018; 6: 113. doi 10.3389/fpubh.2018.00113. Retrieved January 14, 2020, from https://www.ncbi.nlm.nih.gov/pmc/articles/PMC5949337/

SmartLearning (2019I): Baseline - seneste revision 26. November 2019. Internal document. SmartLearning (2019II): SmartLearnings Undervisningsprincipper. Internal document.

SmartLearning (2020): Proces for udvikling og implementering af undervisningsprincipperne. Internal document. 